\title{
Steps for the Future of Bulan Bintang Party
}

\author{
Hasrat Efendi Samosir \\ Universitas Islam Negeri Sumatera Utara, Indonesia \\ hasratefendisamosir@gmail.com
}

\begin{abstract}
The aims of the study discuss about the Steps for the Future of Bulan Bintang Party. This study used qualitative research. The result of this study shows that One of the national work programs that were not optimal during the 2005-2010 term of service of the $P B B$ DPP was the consolidation of the organization and the burden of infrastructure formation in most sub-districts and subdistricts/villages. That the political machinery of party management is one of the strategies to achieve success in the face of general elections. Thus, it is necessary to consolidate the organization and complete the formation of party infrastructure down to the lowest level (Rukun Tetangga/RT). Simultaneous and continuous cadre of members in each party is one of the determinants of progress for the party. However, the reality shows that party regeneration is still relatively limited. Therefore, it is necessary to carry out more massive, intelligent, and measurable cadre cadres in order to meet the qualification needs of party management at all levels, preceded by cadre workshops.
\end{abstract}

Keywords

Covid; PSBB;

unemployment

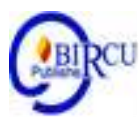

\section{Introduction}

In the 2009 General Election, PBB's vote acquisition was greatly decreased and could not exceed the threshold (PT) of $2.5 \%$, so that it could not place its representatives in the DPR RI. a survey to find out the reasons, with the results: first, the figure of a legislative candidate is unknown or unpopular. Second, party administrators are less well known and not close to the public. Third, programs and issues are not in accordance with the aspirations of the people. Fourth, the image of leaders and administrators is rarely covered by the mass media. Fifth, the performance of legislators and regional heads from the United Nations is not aspirational and less publicized.

In addition to these five factors, the survey results also show that:

1. $53.4 \%$ Recommend that PBB joins (47.8\% with similar political parties and $5.7 \%$ with non-like political parties);

2. $34.8 \%$ recommended that the PBB be retained (27.4\% remained with the name PBB and $7.4 \%$ changed the name);

3. $8.7 \%$ of respondents recommended that $\mathrm{PBB}$ be disbanded;

4. None of the respondents who voted for the PBB in the 2009 elections wanted the PBB to be dissolved. 


\section{Review of Literature}

\subsection{Definition of Politics}

What is politics really? Politics in Arabic is called siyasyah, which is then translated into tactics, or in English it is called Politics. Politics itself does mean clever and wise, which in everyday conversation we seem to interpret as a means used to achieve goals, but political experts themselves admit that it is very difficult to give a definition for political science.

In principle, politics has the scope of the state, because political theory investigates the state as a political institution that affects people's lives, so the state is in motion. Apart from that, politics also investigates ideas, principles, the history of the formation of the state, the nature of the state, as well as the form and purpose of the state, in addition to investigating matters such as elite groups, interest groups, pressure groups, public opinion, the role of political parties, and the existence of elections. The origin of the word politics comes from the Greek word polis which means city state, with politics meaning there is a special relationship between humans who live together, in that relationship arise rules, authority, official behavior, legality of power and finally power. Politics can also be said as wisdom, power, government power,

Politics can be interpreted as art and science, why is it called art, because how many we see politicians or political leaders who are without political science education, but are capable and have tips in politics, because they bring talents that are innate from their inner instincts as political artists., so that he is able to charismatically carry out and play the role of the political wheel of government and power in a practical political order. While politics is said to be a science, because it is knowledge that has objects, subjects, methodologies, systems, terminology, characteristics, theories that are distinctive and specific and universally accepted throughout the world, besides being able to be taught and learned by many people.

Political repositioning shows that opportunistic structures of power, capital or economy, culture and kinship or dynasty were used by the Elites to strengthen their political base in the face of the 2014 legislative elections. The combination of elite position and repositioning patterns in South Nias has implications for the way in political recruitment for nominating members legislative (Manao in Syofian, 2020).

\subsection{Islamic Politics}

Politics in Arabic is called as-Siyasiyah, which was later adopted in Indonesian as a strategy. Political Islam or as-siayasah al-Islamiyah, has the meaning of how Islam views and perspectives on politics. Politics is identified with how to regulate, manage and carry out social and state life in the Islamic system. Islam as a kaffah religion (covering all aspects of life) and a syumul religion (complete and perfect), provides guidelines and rules regarding the state system and the practice of power carried out by a leader. Khalid Ibrahim Jindan in his book The Practice of Islamic Politics, suggests that there are several kinds of politics in Islam. First, the ummah as a political body. Second, the election model that is practiced with the "Bai'ah" election model. Third, the term and practice of "shura" or deliberation which is emphasized in Islam. Fourth, the problem of loyalty and transgression (al-Wala' wal bara') and rebellion (bughat). 
In the context of Islamic Politics, or Siyasa Islam, we find a number of "terms" which indicate that politics is also part of Islamic teachings that must be carried out according to the concept of the teachings of Allah and the Apostle. So in the Islamic political discourse, we will find a number of shapes or forms and faces that become the spirit of Islamic politics, while the terms of Islamic politics are the terms ummah, shura or deliberation, bai'ah, etc. In Islamic societies, as in other world societies, political institutions are constructed in the manner deemed most suitable to promote the outlines of their core values.'

\section{Research Methods}

In the world of research, there are only two schools (types) of research, namely qualitative and quantitative. If qualitative is more theoretical in nature and has a natural setting, quantitative research is verification or theory testing and has a scientific background. The research that the author is doing is a type of qualitative research. Meleong defines qualitative research as a scientific research that aims to understand a phenomenon in a natural social context by prioritizing a process of deep communication interaction between research and the phenomenon under study. Meanwhile, Saryono stated that qualitative research is research that is used to investigate, find, describe, and explain the quality or privilege of unexplained social influences. Measured or described through a quantitative approach. Sugiyono added that the qualitative research method is a research method based on the philosophy of postpositivism, used to examine the condition of natural objects, (as opposed to experimentation) where the researcher is the key instrument, the sampling of data sources is carried out purposively and snowball. triangulation (combined), data analysis is inductive/qualitative, and qualitative research results emphasize meaning rather than generalization.

From the several definitions of qualitative research stated above, the researcher formulates that this type of research is classified as qualitative research where the researcher intends to examine the condition of the object by understanding a phenomenon in a social context with a natural setting that emphasizes the process of deep communication interaction between researchers and phenomena researched. The approach taken is a phenomenological approach by capturing cultural themes related to the analysis of political communication, activities, programs, vision and mission, platforms of struggle, forms of political communication, the results achieved and the obstacles faced in carrying out political communication that became the failure factor in winning the votes of the Muslim constituents of the Regional Leadership Council of the North Sumatran Crescent Star Party (PBB).

The location of this research is focused on two places, namely the secretariat of the party that is the object of research, namely, carried out by the secretariat of the North Sumatra Crescent Star Party DPW. Researchers will also collect data from the North Sumatra KPU, research informants and from the documentations of the two parties. While the time taken is 7 (seven) months, starting from seminars, preliminary studies, postseminar proposal improvement, preparing research instruments, interview guides, data collection. 


\section{Results and Discussion}

From the description of the survey results conducted by the UI Independent Survey Institute above, there are two steps that can be taken by party leaders in connection with the 2014 elections, namely:

1. The UN DPP for the 2010-2015 period will immediately explore the possibility of party mergers.

2. In addition to conducting an assessment as referred to in point 1 above, in the context of the PBB becoming a participant in the 2014 election, the DPP PBB for the 2010-2015 period will immediately carry out the following agenda:

a. In 2010 the problem of party consolidation must be resolved;

b. 2011 is the year of imaging;

c. 2013 was a year of expansion to gauge how popular the UN was;

d. 2014 is a year of maintenance of opportunities and opportunities that must be maintained.

In order to strengthen this agenda, it is required to conduct an annual survey involving an independent survey institution. The UN DPP for the 2010-2015 periods must fight for the participation of the Crescent Star Party in the 2014 General Election.

\subsection{Khatimah}

These are the steps that must be taken by the Central Leadership Council of the Crescent Star Party for the 2010-2015 period in order to reorganize the weaknesses that have existed so far. These steps are carried out simultaneously by taking into account the conditions and changes in the laws and regulations in the political field, especially the law on general elections.

Finally, only to Allah we surrender and may Allah ease our efforts to realize all the wishes of the ummah, cadres, and all party functionaries according to their respective levels.

Billahi at Taufiq wa al Hidayah

Set in: Medan

On: 10 Jumadil Ula $1431 \mathrm{H}$

April 25, $2010 \mathrm{M}$

And the contents of the future steps of the UN Party were all signed by the Leaders of the Third Conference which took place in Medan, respectively; Yasin Ardhy, SH (chairman), H Abdul Haq SH (secretary) with members:

1. Drs Dwianto Ananias

2. Ir.H. Eddy Wahyudin, MBA

3. Drs. H. Suwito Suprayogi, Lc

4. Dr. Ir. H. Masri Sitanggang, MP

5. Drs H. Sudarno Hadi, M.Pd

6. Sugianto, $\mathrm{SH}, \mathrm{MH}$

7. Adolf War Game

The steps to save and determine the future of the Crescent Star Party through the Congress in Medan, became the basis for the North Sumatra United Nations management to work more seriously and seriously so that the PBB could pass the threshold (PT) in the upcoming elections. In addition to these steps, the researcher also found a number of Party recommendations to be implemented in all party structures, especially for DPW and DPC up to PAC and Branch. The recommendations read: 
Conference Recommendations

Based on the tanfidz of existing party documents, the researchers found a number of recommendations in the UN Conference III both internal and external, through Letter Number: 10/TAP/Congress III/2010 with the following contents:

\subsection{Internal}

Realizing and understanding dan Ibrahimas well as the wisdom of failing to fulfill the PT and considering the political struggle to build an Indonesian society based on the value of Islamic teachings is worship, then with patience and trust in Allah, the Big Moon Star family has the obligation to always strive to achieve a better future. In responding to current and future conditions, the strategic steps that are urgent and must be carried out by the DPP of the Crescent Star Party for the 2010-2015 period are:

1. The law on general elections in Indonesia is always changing and usually occurs before the next general election, even though political parties must prepare early in the form of planning and consolidation, because there is certainty and there is no doubt about participation in the general election. Therefore, the DPP PBB for the 2010-2015 period should carefully and continuously follow the developments of trends in changes to the election law and its implications for parties, conduct intensive studies on the direction of changes in the package of political laws.

2. One of the national work programs that were not optimal during the 2005-2010 term of service of the PBB DPP was the consolidation of the organization and the burden of infrastructure formation in most sub-districts and sub-districts/villages. That the political machinery of party management is one of the strategies to achieve success in the face of general elections. Thus, it is necessary to consolidate the organization and complete the formation of party infrastructure down to the lowest level (Rukun Tetangga/RT).

3. Simultaneous and continuous cadre of members in each party is one of the determinants of progress for the party. However, the reality shows that party regeneration is still relatively limited. Therefore, it is necessary to carry out more massive, intelligent, and measured cadre cadres in order to meet the qualification needs of party management at all levels, preceded by cadre workshops.

4. Every political party certainly wants victory in every election, therefore a selective electoral organization (KAPPU) is absolutely imperative to be formed no later than 6 (six) months after the inauguration of the UN DPP for the 2010-2015 period. The discussion was followed by the determination of the electoral district and legislative candidates no later than January 2011.

5. Conduct studies in order to formulate the concepts of enforcement of Islamic law in the territory of the Republic of Indonesia, especially in the Province of Nanggroe Aceh Darussalam in the form of the concept of legislation and regional regulations. Understanding and behavior of Islamic sharia among the big family of the Crescent Star Party, to optimize this understanding and more syar'i behavior, it is necessary to establish a Center for Information and Sharia Studies (PIKSAR) in the form of a special institution.

6. The PBB DPP for the 2010-2015 period revised the PBB DPP decision letter No: SK/1616/2009 regarding changes to SK PP/552/2007 regarding the implementation guidelines for the recruitment of public officials of the Bulaan Bintang Party, especially related to the post-conflict local election so that the authority to get a pair of candidates for regional heads is handed over to the leadership. The party is a level above it. 
7. The UN DPP for the 2010-2015 period together with all levels of party leadership, must carry out a process of positive imagery of the party in a systematic and continuous manner. The imaging process is increasingly enhanced in quantity and quality through various print and electronic media by establishing a special institution that handles it actively, responsively, and professionally.

8. The UN DPP for the 2010-2015 period is to conduct an in-depth study and then formulate the party leadership system at all levels of the party through a mechanism process carried out by deliberation and consensus no later than 1 year after the inauguration of the UN DPP for the 2010-2015 period.

9. In order to maintain the existence of the Crescent Star Party, all ranks of the Party from the DPP to the lowest leadership must strive for a minimum of $5 \%$ of the national valid votes in the 2014 legislative elections.

\subsection{External}

a. Politics and Government

1. Urge the government and parliament to restore the life of the Indonesian National Police Agency under the Ministry of Home Affairs.

2. Urge the government and parliament not to revise the Law on Political Parties and the Law on General Elections (at least three elections).

3. Urge the government and parliament to position KPU members from political parties participating in the election and re-establish the PPI.

4. Urge the government and parliament to realize the existence of a law on food, beverage and drug products that are haram by including the label HARAM.

\section{b. Law enforcement}

1. The government must set clear, measurable and tangible targets for eradicating corruption that can be seen by the wider community.

2. The government must be serious in law enforcement (law enforcement), by reforming law enforcement officers, eradicating judicial mafia and ensuring the independence of legal institutions.

3. For the sake of the integrity of the Unitary State of the Republic of Indonesia, the Presidential Decree of July 5, 1959, in which it expressly stated that "the Jakarta Charter, dated June 22, 1945, animates the 1945 Constitution, and is an integral part of the constitution". For this reason, it is absolutely necessary to have comprehensive, dynamic, fair legislation by taking Islamic law seriously as a source of national law. Accordingly, the Legislative and Executive must implement it.

4. The movement of understanding heretical sects under the guise of Islam is growing and causing divisions among the ummah. In order to maintain the purity of Islamic teachings and the internal harmony of the Muslim ummah (the majority population in this country), it is necessary for the government to be firm in eradicating it by issuing related regulations. In addition, Islamic institutions jointly provide awareness to the public under the coordination of the MUI.

5. Urge the government and parliament to remove the stigma about terrorism associated with certain religions, especially Islam. 


\section{c. Incredible Crime}

The government must immediately take concrete steps to eradicate wood theft, fish theft, smuggling of goods, banking crimes and other crimes that are very disturbing to the public, such as buying and selling children and women, narcotics and pornography and pornography

\section{d. Social Community}

1. Urge the government to immediately issue a Government Regulation related to the Pornography Law.

2. Urge the government to tighten supervision of events and information that is not educational in print and electronic media, including the tourism sector which can damage the nation's morale and attempts to erode the ummah's aqidah.

\section{d. Economy and People's Welfare}

1. The government must immediately take policies to reduce unemployment and poverty and immediately build industries that can absorb more workers by providing business incentives and facilitating investment.

2. Urge the government to provide continuous guidance to small entrepreneurs in order to have strong competitiveness.

3. Urge the government to increase protection for TKI who are abroad.

\section{e. Education}

1. Urge the government and parliament to allocate $20 \%$ of education funds from the APBN/APBD to improve the quality of education, especially the welfare of educators

2. Urge the government and parliament to increase the allocation of funds from the APBN/APBD to improve the quality of education for madrasas and pesantren.

Urge the government to eradicate the practice of commercialization of education.

\section{Conclusion}

One of the national work programs that were not optimal during the 2005-2010 term of service of the PBB DPP was the consolidation of the organization and the burden of infrastructure formation in most sub-districts and sub-districts/villages. That the political machinery of party management is one of the strategies to achieve success in the face of general elections. Thus, it is necessary to consolidate the organization and complete the formation of party infrastructure down to the lowest level (Rukun Tetangga/RT).

Simultaneous and continuous cadre of members in each party is one of the determinants of progress for the party. However, the reality shows that party regeneration is still relatively limited. Therefore, it is necessary to carry out more massive, intelligent, and measurable cadre cadres in order to meet the qualification needs of party management at all levels, preceded by cadre workshops. 


\section{References}

Ahmad, Zainal Abidin. (1973). Piagam Nabi Muhammad Saw. Konstitusi Negara yang pertama di dunia. Jakarta: Bulan Bintang.

Ali Audah. (1995). Sejarah Hidup Muhammad. Jakarta: Lintera Antar Nusa.

Amin, Ahmad. (1961). Fajr a-Islam, Kairo: Maktabat al-Nahdhat al Mishriyat, 1979.Banfield, Edward C, Political Infleunce. New York: The Free Pessof Glencoe.

Bungin, Burhan. (2005). Analisis Data penelitian Kualitatif. Jakarta: RajaGrafindo Persada.

Catlin, G.E.G. (1930). The Study of Principlesof Politics. New York: Macmillan.

Cangara, Hafied. (1998). Pengantar Ilmu Komunikasi. Jakarta: PT Raja Grafindo Persada. Grafindo Persada.

Departemen Agama RI. (2004). Alquran dan Terjemahnya. Jakarta: Karya Insani Indonesia.

Departemen Pendidikan dan Kebudayaan. (1988). Kamus Besar Bahasa Indonesia. Jakarta: Balai Pustaka.

Direktur Jenderal Pembinaan Kelembagaan Islam. (1982). Depag RI, Sejarah dan Kebudayaan Islam. Ujungpandang: IAIN Alauddin Press.

Dudung, Abdurrahman et al. (2002). Sejarah Peradaban Islam dari Masa Klasik hingga Modern. Yogyakarta: Fakultas Adab IAIN Sunan Kali Jaga- Lesfi.

Easton, David. (1984). The Political System. New York: Alfred A Knopf, 1953. Effendy, Onong Ucohjono, Ilmu Komunikasi Teori dan Praktek. Bandung: Remaja Karya. Aditya Bakti.

Effendy, Bahtiar. (1998). Islam dan Negara; Transpormasi Pemikiran dan Praktek Politik Islam di Indonesia. Jakarta: Paramadina.

Eriyanto. (2000). Kekuasaan Otoriter dari Gerakan Penindasan Menuju Politik Hegemoni. Yogyakarta: Pustaka Pelajar.

Guillaume, A. (1972). The Influence of Yudaism on Islam. London: Oxford The Clarenon Press.

Hadi, Sutrisno. (1991). Metodologi Research, Jilid 1 \& 2, Yogyakarta: UGM Press.

Harahap, Syahrin. (2006). Metodologi Studi Tokoh Pemikiran Islam, Medan: Istiqamah Mulya Press.

Haikal, Muhammad Husein, Hayat Muhammad. (1983). Beirut: Dar al-Maarif, (terj)

Harun, Rochajat dan Sumarno Ap. (2006). Komunikasi Politik sebagai suatu pengantar. Bandung: Mandar Maju.

Hisyam, Ibnu. (1955). Sirah al-Nabawiyyah. Kairo: Musthafa al-Bab al-Halabi.

Hitti, Philip K. (1970). History of The Arab. London: The Macmillan Press Ltd.

Iqbal, Muhammad. (2002). Masyarakat Madani Pada Masa Nabi Muhammad Saw. Dalam Miqot, Vol XXVI, No. 2, Juli.

Gaya Media Pratama.

Jasmadi. (1996). Piagam Madinah Dalam Perspektif Dakwah Nabi Muhammad SAW. Medan: PPS IAIN SU.

Kantraprawira, Rusadi. (1983). Sistem Politik Indonesia. Bandung: Sinar Baru.

Katimin. (2007). Politik Islam Indonesia; Membuka Tabir Perjuangan Islam Ideologis Dalam Sejarah Politik Nasional. Bandung: Citapustaka Media. 
Khan, Muhammad Zafrulah, Muhammad. (1980). Seal of the Priphet. London: Routedgeang Kegan Paul.

Kertapati,Ton. (1981). Dasar-Dasar Publisistik. Jakarta: Bina Akasara.

Klalil, yauqi Abu, (terj) Muhammad Abdul ghoffar. (2006). Atlas Alquran. Jakarta: Almahira.

Kholil, Syukur. (2006). Metodologi Penelitian Komunikasi. Bandung: Citapustaka Media.

Pamungkas, Sigit. (2011). Partai Politik; Teori dan Praktek di Indonesia, Sleman Yogyakarta: Perum Griya Suka Permai.

Pulungan, J Suyuthi. (1995). Prinsip-Prinsip Pemerintahan dalam Piagam Madinah ditinjau dari Alquran. Jakarta: Lembaga Studi Islam dan Kemasyarakatan.

Probonegoro, dan Nunik Kleden. (1994). Seni Memahami sebagai Metode Humaniora dalam masyarakat Indonesia. Dalam Jurnal LIPI jilid XXI no. 1, Jakarta: LIPI Press.

Program Pascasarjana IAIN Sumatera Utara. (2006). Pedoman Penulisan Proposal dan Tesis.Medan: PPS IAIN SU.

Rahmat, Jalaluddin. (2003). Psikologi Komunikasi. Bandung: Remaja Rosdakarya.

Rauf, Maswadi, Mappa Nasrun. (1993). Indonesia dan Komunikasi Politik. Jakarta: Gramedia.

Rousdy, Lathief. (1985). Dasar-Dasar Rhetorika Komunikasi dan Informasi. Medan: FA. Rinbow.

Salim, Abdul Muin. (2002). Konsepsi Kekuasaan Politik Dalam Alquran, Jakarta: Raja Grafindo Persada.

Sastropoetro, Santoro. (1990). Pendapat Publik, pendapat umum dan pendapat khalayak dalam komunikasi sosial. Bandung: Remaja Rosdakarya.

Shihab, Quraish. (1996). Membumikan Alquran. Bandung: Mizan.

Sjadzali, Munawir. (1993). Islam dan Tata Negara ; Ajaran, Sejarah dan Pemikiran. Jakarta: UI-Press.

Soesanto, Astrid S. (1975). Komunikasi Sosial. Jakarta: Bina Cipta.

Sukardja, Ahmad. (1995). Piagam Madinah dan Undang-Undang Dasar 1945 ; Kajian perbandingan tentang dasar hidup bersama dalam masyarakat yang majemuk. Jakarta: UI- Press.

Syofian, E. et al. (2020). Identity Politics in the 2018 Regional Head Elections for the Governor and Deputy Governor of North Sumatra. Budapest International Research and Critics Institute-Journal (BIRCI-Journal). P. 3675-3685

Surur,Muhammad Jamal al-Din. (1977). Qiyam al-Dawlah al-“Arabiyyah al-Islamiyah fii Hayati Muhammad Saw. Al-Qahirah: Daar al-Fikr al-'Araby.

Syafiie. (2010). Inu Kencana, Ilmu Politik, Jakarta: Rineka Cipta.

West, Richard, et al. (2007). Introducing Communication Theory Analysis and Aplication. Singapore: Mc Grew Hill.

Wok, Saodah, et al. (2004). Teori-teori komunikasi. Kuala Lumpur: Percetakan Cergas (M) Sdn, Bhd. 